\title{
Population biobanking in selected European countries and proposed model for a Polish national DNA bank
}

\author{
Jarosław Sak • Jakub Pawlikowski • \\ Mariusz Goniewicz • Magdalena Witt
}

Received: 28 November 2011 /Revised: 28 December 2011 / Accepted: 2 January 2012 /Published online: 27 January 2012

(C) The Author(s) 2012. This article is published with open access at Springerlink.com

\begin{abstract}
Population biobanks offer new opportunities for public health, are rudimentary for the development of its new branch called Public Health Genomics, and are important for translational research. This article presents organizational models of population biobanks in selected European countries. Review of bibliography and websites of European population biobanks (UK, Spain, Estonia). Some countries establish national genomic biobanks (DNA banks) in order to conduct research on new methods of prevention, diagnosis and treatment of the genetic and lifestyle diseases and on pharmacogenetic research. Individual countries have developed different organizational models of these institutions and specific legal regulations regarding various ways of obtaining genetic data from the inhabitants, donors' rights, organizational and legal aspects. Population biobanks in European countries were funded in different manners. In light of these solutions, the authors discuss prospects of establishing a Polish national genomic biobank
\end{abstract}

\author{
J. Sak $(\bowtie) \cdot J$. Pawlikowski \\ Department of Ethics and Human Philosophy, \\ Medical University of Lublin, \\ ul. Szkolna 18, \\ 20-124 Lublin, Poland \\ e-mail: jareksak@tlen.pl \\ J. Pawlikowski \\ Institute of Rural Health, \\ Lublin, Poland \\ M. Goniewicz \\ Emergency Medicine Unit, Medical University of Lublin, \\ Lublin, Poland \\ M. Witt \\ Department of Disaster Medicine, \\ University of Medical Sciences Poznan, \\ Poznan, Poland
}

for research purpose. They propose the creation of such an institution based on the existing network of blood-donation centres and clinical biobanks in Poland.

Keywords DNA banking · Genetic epidemiology · Population biobanks $\cdot$ Public health genomics

\section{Introduction}

Biobanks, gradually begin to play an increasingly important role in studying the determinants of populations' health and in shaping proper prevention programs and health policies. The Expert Group of the European Commission defines biobanks as various types of "biological samples themselves, plus the related databases" (http://ec.europa.eu). The Oganisation for Economic Co-operation and Development (OECD) documents, on the other hand, characterize biobanks as „structured resources that can be used for the purpose of genetic research and which include: human biological materials and/or information generated from the analysis of the same; and extensive associated information" (http://www.oecd.org). They also emphasize that biobanks can be used in research on human genetics and the relationships between genetic, environmental and life-style factors in shaping population health (http://www.oecd.org). Biobanks are diverse in terms of the purpose for which they collect the biological material. They exist for clinical purposes (transplants, blood transfusions, genetic diagnosis), research (e.g. research on neurodegenerative diseases, monozygotic siblings, isolated populations, pharmacogenetic studies), police and courts, and others (e.g. Educational purpose). Some of the projects related to biobanking are carried out on a large-scale, as exemplified by the genomic biobanks of entire populations, also called population 
biobanks (Swede et al. 2007). Public trust is the most important predictor of the publics' intention to participate in biobank research (Crithchley et al. 2010; Kettis-Lindblad et al. 2005).

The most important hopes connected with the development of biobanks are: a better recognition of genetic and environmental factors of the hereditary diseases, examining people's susceptibility to specific diseases (Frazier et al. 2008; Wang et al. 2010; Brozek et al. 2011; Myszka et al. 2011); more effective personalized preventive care (e.g. the modern spectrometry allows detection of more than 30 metabolic disorders using the neonatal screening blood spot) (Sharrard and Pollitt 2007), adaptation of the treatment to the patient's individual genetic characteristics by development of pharmacogenetics (personalized medicine) (Roses 2000; Matimba et al. 2008; Szczepanek et al. 2011) inventing innovative drug therapies and discovering new biomarkers of many diseases with the use of modern sequencing technologies (Pareek et al. 2011). DNA obtained from archived tissues, blood films and slides may be useful to establish the molecular diagnosis of a deceased patient and this information may be of value for relatives even after 10-20 years (Godard et al. 2003). Population biobanks may also allow to trace the evolution of genetic changes in subsequent generations, allowing an improved understanding of pathogenic mechanisms leading to the development of many diseases caused by hereditary factors or the interaction of genetic and environmental factors (Founti et al. 2009; Inczédy-Farkas et al. 2010). The development of population biobanks will also isolate the group of patients unsusceptible to certain diseases, who will not require the unnecessary and expensive diagnostic, which in turn will allow for a rational management of financial resources in the health care system (Roden et al. 2008). These opportunities contributed to the development of a new field within public health called Community Genetics or Public Health Genet$i c s /$ Genomics (PHG). PHG is defined as the responsible and effective translation of genome-based knowledge and technologies for the benefit of population health (definition of Bellagio Group on Public Health Genomics) (http://www. phgen.nrw.de). PHD assesses the impact of genes and their interaction with behavior, diet (nutrigenomics) and the environment on the population's health (e.g. ALSPAC the Avon Longitudinal Study of Pregnancy and Childhood - a gene-environmental research focused on children's health) (www.alspac.bristol.ac.uk).

There are many international initiatives in PHG that promote the translation of genome-based science and technology into improvements in population health, e.g. HuGENet (Human Genome Epidemiology Network) (www.cdc. gov/genomics/), P3G Consortium (Public Population Project in Genomics) (www.p3g.org/), GraPH-Int (The Genome-based Research and Population Health International Network) (www.graphint.org/) and GRC (Genomic Resource Centre) developed by WHO (www.graphint.org/). Noteworthy is the project of the Biobanking and Biomolecular Resources Research Infrastructure (BBMRI) (www.who.int/genomics/en/). Its main purpose is to connect, within the next few years, the existing genomic biobanks from different countries of the European Union in one research network. This may become the basis for an integrated research, leading to a better understanding of factors affecting the health disparities in European countries, and to a more reasonable measure of improving the health of the European population.

The objective of this article is to present organizational solutions to population biobanks in selected European countries. It appears that population biobanks are in fact diverse in this respect, and not only researchers and development centres possessing public finances are involved in the process of their creation, but in recent years, under the auspices of associations, foundations and private companies multiply the projects of gathering genetic materials. Currently, population biobanks are experiencing a rapid development in European countries, which accelerated sharply after sequencing of the human genome in 2000. Gradually, they become a part of the health care system not only by creating new opportunities for research, but also by giving the opportunity to implement effective measures to preserve the health of the European population (Swede et al. 2007; McCarthy et al. 2008; Litton 2011). In light of organizational solutions of European contries, the authors discuss prospects of establishing a Polish national genomic biobank for research purpose.

\section{Methods}

Review of bibliography and websites of European population biobanks. We reviewed in PubMed database articles which concern population biobanks focusing on organizational models of these institutions and specific legal regulations regarding various ways of obtaining genetic data from the inhabitants, donors' rights, organizational and legal aspects. We analysed more deeply UK Biobank, Spanish national biobank and Estonian biobank because of their interesting and different organizational aspects that can be used in establishement of new population biobanks. Model of a proposed Polish national genomic biobank for research purposes was discussed regarding Polish organizational and legal conditions.

\section{Results}

Contemporary, an increasing number of projects on population biobanks, aimed at collecting biological samples and 
data on people belonging to a particular population appear. Some countries establish national genomic biobanks (DNA banks) in the hope of an advanced understanding and improved prevention of genetic diseases (Hirtzlin et al. 2003). It is calculated that at the end of 2007 there were about 120 population biobanks worldwide, mainly in Europe and North America but also in Asia (e.g. China). In Europe, most active countries in the creation of population biobanks are the countries of Western Europe and Scandinavia. The countries of Central and Eastern Europe, however, have already implemented such a project in Estonia, and Hungary and Poland are in the process of its preparation (Pawlikowski and Sak 2010). Below: there are three different organizational models of genomic biobanking: the British, Spanish and Estonian.

\section{UK Biobank}

The UK Biobank was created in order to conduct research on new methods of prevention, diagnosis and treatment of the genetic and lifestyle diseases. The Wellcome Trust Foundation, as well as public entities (Medical Research Council, the Scottish Government, the British Heart Foundation, and the Northwest Regional Development Agency) played an important role in its creation. The Scientific Committee and the international bioethical committee supervized these activities. What is more, there were six regional centres working together and 22 British universities involved. First preparations for establishing of the UK Biobank occurred in the late 1990s of the twentieth century. In 2000-2001 public consultations concerning the public perception of biobanking were conducted. In 2006, a pilot study on a group of 4000 residents of Manchester was carried out and relevant legal regulations established (www.ukbiobank.ac.uk). In the next phase of creating the biobank, after planning of the recruitment process based on drawn conclusions from the pilot study, the UK Biobank obtained samples from more than 500 thousand people aged 40-69. Participants were voluntarily recruited based on the data contained in the databases of the National Health Service. Founders of the biobank distributed to hundreds of thousands of potential donors an invitation to participate in the project. Recipients, who agreed to participate in the study, gave blood, urine and saliva samples; passed the basic diagnostic tests and filled out a questionnaire. Acquired genomic samples are kept for a period of 20-30 years, and made available as anonymous only to researchers' whose projects receive the approval of the ethics committee. Scientists from abroad may also apply for the access to the biobank's resources. Gaining profits from the research may be allowed, e.g. by pharmaceutical companies which will conduct studies with the usage of these resources (Yuille et al. 2010). The test results are not made available to donors; however, they have a possibility of withdrawing data from the database. Biobank is insured against any damage related to the donation or storage of samples from the participants of the study (http://www.ukbiobank.ac.uk/). An important feature of the UK Biobank is its openness to the multicultural and multilingual potential donors living in the United Kingdom. Information materials intended for potential donors are translated into many vernacular languages.

\section{Spanish National Biobank (Banco Nacional de ADN)}

Spanish National Biobank (Banco Nacional de ADN) was established in 2004 by the Genome Spain Foundation (Fundacion Genome Espana), in collaboration with the University of Salamanca. The purpose of its creation was to support research on genetic diversity of the population living in Spain, the development of emerging diseases in the process of human evolution and development of new treatments of lifestyle diseases, including pharmacogenetic research. The specific objectives of El Banco Nacional de $A D N$ include the study of determinants of susceptibility to certain diseases, early diagnosis, improvement of disease classification, the search for new prognostic factors, and optimization of individual treatment, monitoring of effects of treatment, and transferring the results of basic examinations to clinical reality.

Biobank centre is located in Salamanca, at the local university, and the sanitary inspectorate of the Castile and Leon province, the founding the Spanish Genome Foundation, an external scientific committee and a bioethical committee, exercises supervision. The last two supervisors have international members. The advisory group includes representatives of all regional blood donation centres and blood banks. Apart from the biobanks' headquarters, since 2006 the biobank consists of four research institutes from other provinces of Spain, which specialize in research on certain diseases. Collecting samples is based on cooperation with the regional blood donation centres and blood banks. These institutions take samples of blood and are responsible for collecting data and completing the appropriate survey questionnaire containing questions directed to the donor about his lifestyle, diet, family medical history, etc. DNA samples are sent to the headquarters in Salamanca, where they are encoded, prepared and stored. Access to the specimens is available for researchers from Spain and those from abroad who collaborate with the Spanish scientists. The ethics committee must approve research projects.

In 2006, an additional network of specialized centres and research networks on specific diseases: cardiovascular diseases (Barcelona), metabolic (Barcelona), neuropsychiatric (Reus) and oncology (Salamanca), was created. Specialized centres collect, store and conduct tests on samples of biological material from persons suffering from specific types 
of diseases, e.g. research centre for cardiovascular diseases collects samples from individuals after myocardial infarction, coronary artery disease, hypertension, arrhythmia, etc. These centres collaborate with other national centres conducting research in the same fields. The donors have the opportunity to withdraw their consent and samples collected by the biobank, however they do not have access to individual test results, because samples sent to the researchers are anonymized, namely where the personal data and the genetic data of the donor are irreversibly separated (http:// www.bancoadn.org/en/home.htm). Available for researchers is therefore the sample with genomic data obtained concerning the state of health of the donor but without any possibility of restoring his identity.

\section{Estonian population biobank (Estonian Gene Bank)}

Estonian Genome Project was the basis for the creation of the population GenBank, whose goal is to gather samples from approximately 1 million inhabitants of Estonia and Latvia. The legal basis for its establishment was a relevant legal act (Human Genome Research Act), which came into force in 2001. It regulated the research on human genetics and the protection of the donors (confidentiality, nondiscrimination by insurers and employers), and called into existence a national genomic biobank. Participation in the project was voluntary and the participants had access to their results (the right to know), but also had a guaranteed right not to know. They could withdraw the previously granted consent and demand the destruction of data allowing for their identification. Biobank is supervized by: a bioethical committee (28 members), a supervisory committee (consisting of nine members of parliament, government and the Estonian Academy of Sciences). Funding is based on the principles of public-private partnership. By agreement with the government, the project is pursued by a private nonprofit foundation (Estonian Genome Project Foundation), which became the legal owner of the collected material and data. The right to access the data is given to the family doctors (who take care of the donors) and researchers working in the Estonian research institutes; however, the Ethics Committee must approve their project. Intellectual property rights are shared between researchers and the foundation.

In the first phase of the project (until 2003), about 100 family doctors were involved and samples were taken from about 10,000 people. In the second (main) phase, between the years 2003-2007, it was intended to gather samples from approximately three-quarters of the country's population (the population of Estonia, according to data from 2010 was $1,340,000$ people (http://www.stat.ee/main-indicators) engaging in it about 800 persons who collected these samples. This plan was not fully executed. In 2009, the biobank gathered samples and data from 40,000 donors, and at the end of 2010 had only 50,000 samples. Each research participant gave about $50 \mathrm{ml}$ of blood and filled out a questionnaire which included questions on personal data, environmental conditions, diet, workplace, lifestyle, clinical data (e.g. prior and current diseases), and family medical history to a third generation back. After collecting of the biological material, personal data assigned to samples were coded. Informed consent form was kept in the coding centre, which is also responsible for the anonymization of data or if necessary for the identification of donors (e.g. in the case of a request to withdraw data from the biobank) (http://www. geenivaramu.ee/index.php?id=462).

Discussion and prospects of creating a population genomic biobank in Poland

Population biobanks were organized in a different manners. For this purpose new, distinct from the existing institutions that collects samples of biological material from volunteers, or used existing samples and data after obtaining a new consent from the donors were created. Additional possibility was the creation of systems of cooperation between existing biobanking institutions (e.g. blood-donation centres.). Individual countries have developed different organizational models of these institutions and specific methods of legal regulations (Deschenes and Sallke 2005).

The British and Estonian model seem quite expensive, what is more, the British model is based on specific, state system of National Health Service. The Spanish model, in turn, is characterized by economy and simplicity of the organizational structure (using the existing organizational structure of regional blood donation centres) and at the same time is tailored to the population inhabiting a large area of varying population density. A valuable component of the collaboration with general practitioners included in the Estonian solution, or the clear focus on selected donors in the British biobank (including those in a specific age group) should be noted. A good concept is to work with leading scientific institutions conducting research on specific hereditary diseases (as in the case of the Spanish biobank) and medical universities (e.g. UK Biobank), which will allow for a rational and effective management of accumulated scientific resources. It is extremely important to create an appropriate infrastructure and data protection system, which will allow for cooperation with other national and foreign scientific centres and within the BBMRI network (Kauffman and Cambon-Thomsen 2008; Dhir et al. 2008; Gostev et al. 2011; Asslaber and Zatloukal 2007).

Implementation of any new population biobank project should be preceded by a serious social debate, public opinion surveys and the introduction of the necessary legal changes governing the biobank in accordance with the recommendations of international organizations (Crithchley et 
al. 2010; Winickoff and Neumann 2005; http://www.oecd. org). The process of establishing a new genomic biobanks (e.g. the Polish genomic biobank), should rely on the selected items from other models and take into account local organizational, legal and social conditions.

Currently in Poland, there is no nationwide organization obtaining genetic material for population studies (Pawlikowski et al. 2010). There are only local (university or working at the regional oncology centres) facilities, which obtain genetic material for scientific research in a very limited extent. Contemporarily in Poland, discussion began on the subject of organizational, legal and ethical basis of the creation of a national genomic biobank.

Results of the expertise, completed in November 2009 suggest the possibility of creating such a biobank in Polish conditions (Pawlikowski and Sak 2010). Organizational structure of the Polish genomic biobank should consist of two levels, i.e. composed of a superior national coordinating centre and subordinate regional, biobanking and specialized centres (targeted on research on specific disease entities). Regional biobanking centres together with specialized biobanks should obtain samples and data from donors and transfer them to the national coordinating centre where samples and data should be encoded, processed and stored (Fig. 1).
The establishment, from the first, of a population biobank in Polish conditions would be a very expensive and timeconsuming task. It would be more beneficial to base it on the already existing Polish biobanking institutions, e.g. primarily on the blood donation centres and research centres. They have qualified staff and infrastructure, which after necessary modifications (and possibly a small expansion) could lead to their integration into the structure of a national genomic biobank. In organizational terms, it would be best to include the already existing biobanking institutions as "sectors" of the system of the Polish genomic biobank. They could retain the availability of the realization of the existing tasks, and simultaneously make available facilities and personnel for the needs of population biobanking.

Established a few years ego, National Centre for Tissue and Cell Banking (Krajowe Centrum Bankowania Tkanek $i$ Komórek - KCBTiK) could serve as a national coordinating centre. Until now, the tasks undertaken by KCBTiK was the coordination of the activities of other national and regional tissue and cell banks (biobanks created mainly for clinical and transplantation purposes), and acting as a place of reference, consultation and supervision in strictly medical terms. Sectoral use of KCBTiK as a national coordinating centre of the Polish population biobank would be beneficial due to the possibility of inclusion into the newly formed
Fig. 1 Two-level structure of the project of the Polish National Genomic Biobank and the system of supervision

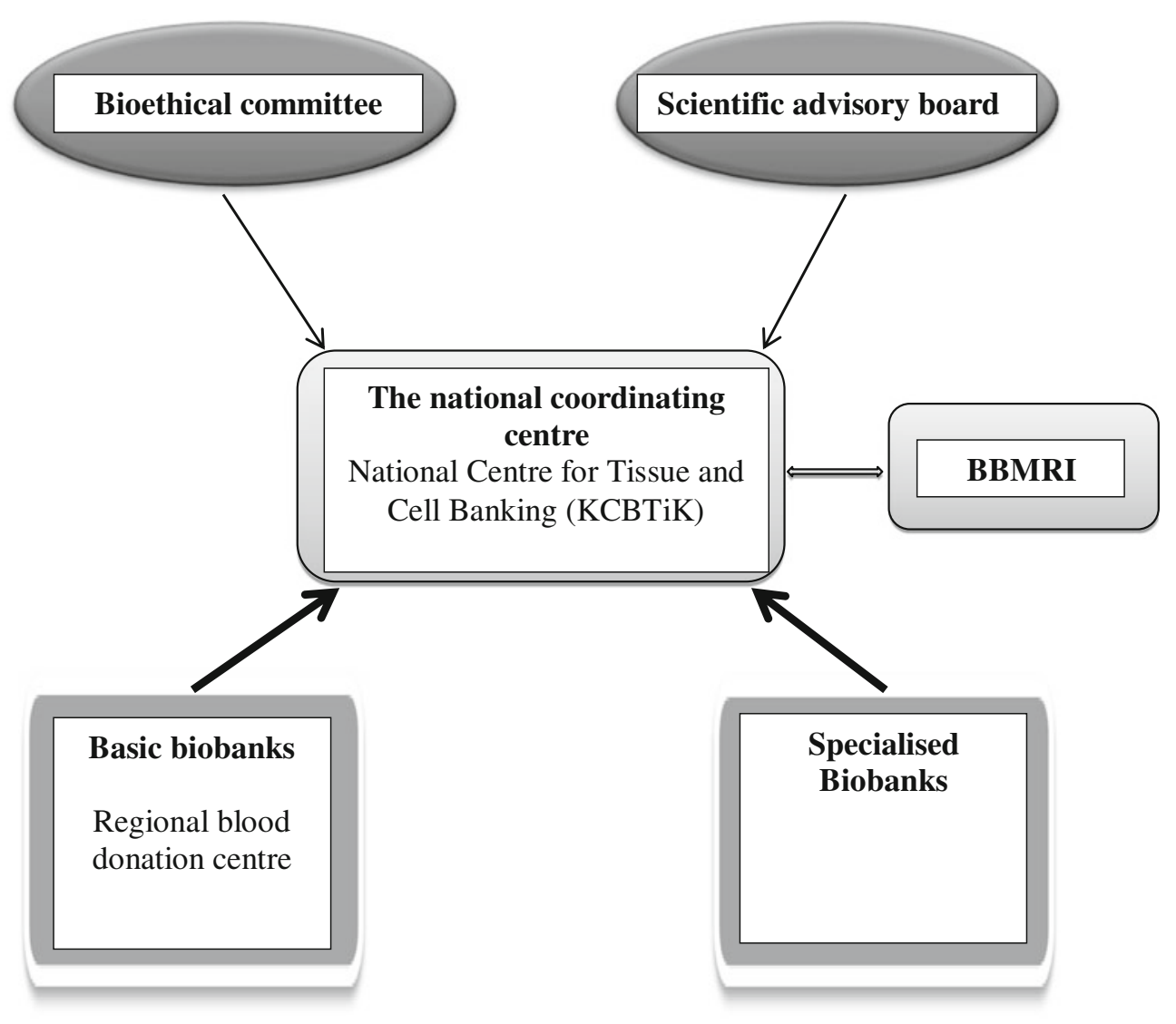


biobank, the existing tissue and cells biobanks, which currently report their activities to the KCBTiK (Fig. 1).

The regional biobanking centres could be based on the regional blood donation and haemotherapy centres in Poland. The already existing research centres (medical universities, oncology centres, Polish Academy of Sciences, genetic diagnostic centres) may fulfil the function of specialist biobanks directed at the diagnosis of certain types of diseases:

It is worthly to postulate for the establishment of an external scientific committee and ethics committee for the supervision on the correctness of the collection, storage and transfer of the genetic material and data for scientific research. In terms of Polish legal solutions currently in force, there should be an amendment of the "Transplant act" (Ustawa z dnia 1 lipca 2005r) or a new law should be written which would autonomously and comprehensively regulate the issue of biobanking. In the case of a successful process of creating a national biobank in Poland for the purpose of genomic research there is the possibility of incorporating it into other European biobanks and other entities conducting research within the confines of currently forming Biobanking and Biomolecular Resources Research Infrastructure (BBMRI) (http://www.bbmri.eu/).

\section{Key points}

- Population biobanks are important for the development of the public health genomics and personalized medicine.

- Some European countries have developed different organizational models of population biobanks and specific legal regulations.

- Population biobanks can be created in collaboration with universities, general practitioners, blood donation centres and scientific research institutes.

- Population biobanks can be founded basing on the public-privacy partnership.

Open Access This article is distributed under the terms of the Creative Commons Attribution Noncommercial License which permits any noncommercial use, distribution, and reproduction in any medium, provided the original author(s) and source are credited.

\section{References}

Asslaber M, Zatloukal K (2007) (Biobanks: transnational, European and global networks. Brief Funct Gen Prot 6:193-201

Brozek I, Cybulska C, Ratajska M, Piatkowska M, Kluska A, Balabas A, Dabrowska M, Nowakowska D, Niwinska A, Pamula-Pilat J, Tecza K, Pekala W, Rembowska J, Nowicka K, Mosor M, Januszkiewicz-Lewandowska D, Rachtan J, Grzybowska E,
Nowak J, Steffen J, Limon J (2011) Prevalence of the most frequent BRCA1 mutations in Polish population. J Appl Genet 52:325-330

Crithchley C, Nicol D, Otlowski M, Stranger M (2010) Predicting intention to biobank: a national survey. Eur J Publ Health. doi:10.1093/eurpub/ckq136

Deschenes M, Sallke C (2005) Accountability in population biobanking: comparative approaches. J Law Med Ethics 33:40-53

Dhir R, Patel AA, Winters S, Bisceglia M, Swanson D, Aamodt R, Becich MJ (2008) A multidisciplinary approach to honest broker services for tissue banks and clinical data: a pragmatic and practical model. Cancer 113:1705-1715

Founti P, Topouzis F, van Koolwijk L, Traverso CE, Pfeiffer N, Viswanathan AC (2009) Biobanks and the importance of detailed phenotyping: a case study-the European Glaucome Society GlaucoGENE project. Br J Ophthalmol 93:577-581

Frazier L, Sparks E, Sanner JE (2008) Biobanks and biomarker research in cardiovascular disease. J Cardiovasc Nurs 23:153-158

Godard B, Schmidtke J, Cassiman J, Ayme S (2003) Data storage and DNA banking for biomedical research: informed consent, confidentiality, quality issues, ownership, return of benefits. A professional perspective. Eur J Hum Gen 11(Suppl 2):88-122

Gostev M, Fernandez-Banet J, Rung J, Dietrich J, Prokopenko I, Ripatti S, McCarthy MI, Brazma A, Krestyaninova M (2011) SAIL - a software system for sample and phenotype availability across biobanks and cohorts. Bioinformatics 27:589-591

Hirtzlin I et al (2003) An empirical survey on biobanking of human genetic material and data in six EU countries. Eur J Hum Gen 11:475-488

Inczédy-Farkas G, Benkovits J, Balogh N, Almos P, Scholtz B, Zahuczky G, Török Z, Nagy K, Réthelyi J, Makkos Z, KassaiFarkas A, Egerházy A, Tuzko J, Janka Z, Bitter I, Németh G, Nagy L, Molnár MJ (2010) SCHIZOBANK - The Hungarian national schizophrenia biobank and its role in schizophrenia research and in personalized medicine. Orv Hetil 151:1403-1408

Kauffman F, Cambon-Thomsen A (2008) Tracing biological collections: between books and clinical trials. JAMA 299:2316-2318

Kettis-Lindblad A, Ring L, Vibirth E, Hansson M (2005) Genetic research and donation of tissue samples to biobanks. What do potential sample donors in the Swedish general public think? Eur J Public Health 15:1-8

Litton JE (2011) Biobank informatics: connecting genotypes and phenotypes. Methods Mol Biol 675:343-361

Matimba A, Oluka M, Ebeshi BU, Sayi J, Bolaji O, Guantai A, Masimirembwa C (2008) Establishment of a biobank and pharmacogenetics database of African populations. Eur J Hum Genet 16:780-783

McCarthy MI, Abecasis GR, Cardon LR, Goldstein DB, Little J, Ioannidis JP, Hirschhorn JN (2008) Genome-wide association studies for complex traits: consensus, uncertainty and challenges. Nat Rev Genet 9:356-369

Myszka A, Karpinski P, Slezak R, Czemarmazowicz H, Stembalska A, Gil J, Laczmanska I, Bednarczyk D, Szmida E, Sasiadek MM (2011) Irrelevance of CHEK2 variants to diagnosis of breast/ovarian cancer predisposition in Polish cohort. J Appl Genet 52:185-191

Pareek C, Smoczynski R, Tretyn A (2011) Sequencing technologies and genome sequencing. J Appl Genet 52:413-435

Pawlikowski J, Sak J (2010) Studium wykonalności stworzenia w Polsce Krajowego Biobanku Genomowego dla badań naukowych opartego na istniejących instytucjach biobankujących. Ekspertyza nr 301DWB/R/2010 wykonana na zamówienie Ministerstwa Nauki i Szkolnictwa Wyższego Rządu Rzeczpospolitej Polskiej. [Opportunity of creating a Polish National genomic biobank for research purpose based on existing biobanking institutions. Report No. $301 \mathrm{DWB} / \mathrm{R} / 2010$ ordered by the Ministry of Science and Higher Education of the Government of the Polish Republic. 2010] 
Pawlikowski J, Sak J, Marczewski K (2010) The analysis of the ethical, organizational and legal aspects of Polish biobanks activity. Eur J Publ Health 20:707-710

Roden DM, Pulley JM, Basford M, Bernard GR, Wright-Clayton E, Balser JR, Masys DR (2008) Development of a large-scale identified DNA biobank to enable personalized medicine. Clin Pharmacol Ther 84:362-369

Roses A (2000) Pharmacogenetics and the practise of medicine. Nature 405:857-865

Sharrard M, Pollitt R (2007) Metabolic screening in children: newborn screening for metabolic diseases past, present and future. Ped Child Health 17(7):273-278

Swede H, Stone CL, Norwood AR (2007) National population based biobanks for genetic research. Genet Med 9:141-149

Szczepanek J, Jarzab M, Oczko-Wojciechowska M, Kowalska M, Tretyn A, Haus O, Pogorzala M, Wysocki M, Jarzab B, Styczynski J (2011) Gene expression signatures and ex vivo drug sensitivity profiles in children with acute lymphoblastic leukemia. J Appl Genet. doi:10.1007/s13353-011-0073-x

Ustawa z dnia 1 lipca 2005r. o pobieraniu, przechowywaniu i przeszczepianiu komórek, tkanek i narządów. Dz.U. z 2005r. Nr 169, poz. 1411.
Wang KS, Mullersman JE, Liu XF (2010) Family-based association analysis of the MAPT gene in Parkinson disease. J Appl Genet 51:509-514

Winickoff DE, Neumann LB (2005) Towards a social contract for genomics: property and the public in the "Biotrust" model. Genom Soc Policy 1:8-21

Yuille M et al (2010) The UK DNA banking network: a "fair access" biobank. Cell Tissue Bank 11:241-251

\section{Internet Pages}

www.ukbiobank.ac.uk/docs/UKBProtocol.pdf

http://www.oecd.org/document/12/0,3343, en 264934537 $40302092 \quad 1 \quad 1 \quad 1 \quad 1,00 \& \&$ \&en-USS 01DBC.html

http://ec.europa.eu/research/conferences/2004/genetic/pdf/ recommendations en.pdf (access: 4.03.2011)

http://www.oecd.org/document/12/0,3343,en_2649_34537 $40302092 \quad 1 \quad 1 \quad 1 \quad 1,00 \& \&$ en-USS 01DBC.html

http://www.phgen.nrw.de/typo3/fileadmin/downloads/Manual Versand_Bellagio_Report-230106.pdf 